\title{
Configuration of the Psymberin Amide Side Chain
}

\section{Supplemental Information}

\author{
Lawrence J. Williams and Sezgin Kiren \\ Contribution from the Department of Chemistry and Chemical Biology, Rutgers, The State University of \\ New Jersey, Piscataway, New Jersey 08854, USA
}

General: Starting materials, reagents and solvents were purchased from commercial suppliers (Aldrich, Fischer, Advanced ChemTech) and used without further purification unless otherwise stated. All reactions were conducted in oven-dried $\left(135{ }^{\circ} \mathrm{C}\right)$ glassware under an inert atmosphere of argon. The progress of reactions was monitored by silica gel thin layer chromatography (tlc) plates (mesh size $60 \AA$ with fluorescent indicator, SigmaAldrich), visualized under UV and charred using cerium or anisaldehyde stain. Products were purified by flash column chromatography (FCC) on 120-400 mesh silica gel (Fisher). Infrared (FTIR) spectra were recorded on an ATI Mattson Genesis Series FTInfrared spectrophotometer. Proton nuclear magnetic resonance spectra $\left({ }^{1} \mathrm{H}\right.$ NMR) were recorded on either a Varian-300 instrument (300 MHz) or a Varian-400 instrument (400 $\mathrm{MHz}$ ) unless otherwise stated. Chemical shifts are reported in ppm relative to residual $\mathrm{CHCl}_{3}$ signal. Data is reported as follows: chemical shift, integration, multiplicity ( $\mathrm{s}=$ singlet, $\mathrm{d}$ =doublet, $\mathrm{t}=$ triplet, $\mathrm{q}=$ quartet, $\mathrm{br}=$ broad, $\mathrm{m}=$ multiplet), and coupling constants $(\mathrm{Hz})$. Carbon nuclear magnetic resonance spectra $\left({ }^{13} \mathrm{C} \mathrm{NMR}\right)$ were recorded on either a Varian-300 instrument (75 MHz) or a Varian-400 instrument (100 MHz) unless otherwise stated. Optical rotations were recorded at $25{ }^{\circ} \mathrm{C}$ using the sodium D line (589 $\mathrm{nm}$ ), on a Perkin-Elmer 241 polarimeter. Mass spectra were recorded on a Finnigan LCQ-DUO mass spectrometer. 


\section{Experimental procedures}

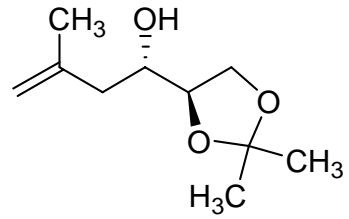

5

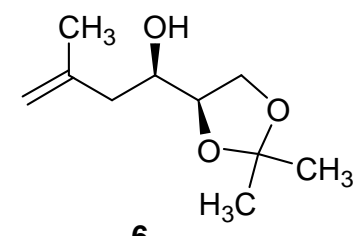

To a solution of methallylmagnesium chloride in THF $(0.0375$ mole, $0.8 \mathrm{M})$ at $-78{ }^{\circ} \mathrm{C}$ was added slowly a solution of protected glyceraldeyhde $4(0.025$ mole, $3.25 \mathrm{~g})$ in THF $(62.5 \mathrm{ml})$ down the inside of the flask. The reaction mixture was allowed to warm to room temperature, and stirred for additional $4 \mathrm{~h}$. The mixture was then cooled to $-78{ }^{\circ} \mathrm{C}$, quenched with saturated $\mathrm{NH}_{4} \mathrm{Cl}$ solution, extracted with $\mathrm{Et}_{2} \mathrm{O}$, and dried over $\mathrm{Na}_{2} \mathrm{SO}_{4}$. Solvent was evaporated and the residue was purified by FCC using hexane:acetone $(15: 1)$ as eluent to give 5 and $\mathbf{6}$ as a colorless oil $(3.4 \mathrm{~g}, 74 \%)$. The ratio anti:syn alcohol was 4:3, as determined by ${ }^{1} \mathrm{H}-\mathrm{NMR}$. $\mathrm{R}_{\mathrm{F}} 0.22$ (15:1-hexane:acetone); IR $v_{\max }\left(\right.$ neat)/cm ${ }^{-1} 3475$, 3057, 2986, 1648, 1067; $\delta_{\mathrm{H}}\left(400 \mathrm{MHz}, \mathrm{CDCl}_{3}\right)$ 4.86-4.85 (2H, brs), 4.79-4.78 (2H, brs), 4.04-3.65 (8H, m), 2.29-2.05 (6H, m), 1.75 (6H, brs) 1.42-1.40 (6H, s), 1.35-1.34 (6H, s); $\delta_{\mathrm{C}}\left(100 \mathrm{MHz}, \mathrm{CDCl}_{3}\right) 141.9,141.7,113.57,113.50,109.3,109.0,78.6,78.3,69.8,68.8$, 65.9, 65.3, 42.0, 41.7, 26.5 (two signals), 25.27, 25.25, 22.4, 22.3; $\mathrm{m} / z$ (ESIMS) found: $187(\mathrm{M}+1)^{+}$; calcd: 187 .
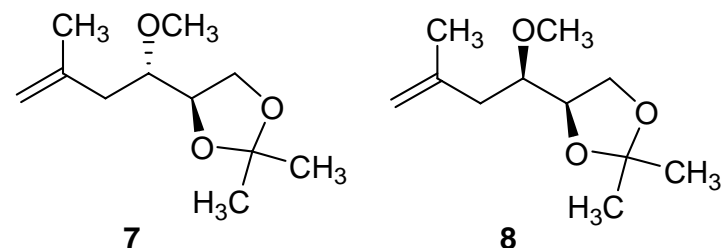

The mixture of 5 and $\mathbf{6}(1.25 \mathrm{~g}, 6.7 \mathrm{mmol})$ was dissolved in THF (12 ml), and cooled to 0 ${ }^{\circ} \mathrm{C}$. $\mathrm{NaH}$ (484 mg, $12.1 \mathrm{mmol}, 60 \%$ dispersion in mineral oil) was added and the mixture was stirred for $15 \mathrm{~min}$. To this $\mathrm{CH}_{3} \mathrm{I}(1.90 \mathrm{~g}, 0.84 \mathrm{ml}, 13.4 \mathrm{mmol})$ was added and the mixture was allowed to warm to room temperature and stirred over $12 \mathrm{~h}$. The reaction mixture was quenched with sat. $\mathrm{NH}_{4} \mathrm{Cl}$, extracted with $\mathrm{Et}_{2} \mathrm{O}$ and dried over $\mathrm{Na}_{2} \mathrm{SO}_{4}$. After removing the solvent in vacuo, the residue was purified by FCC using with hexane:acetone (70:1) as eluent to give $657 \mathrm{mg}$ (49\%) anti isomer 7 and $523 \mathrm{mg}$ (39\%) syn isomer 8 as colorless oils (total yield 93\%). Anti isomer 7; $\mathrm{R}_{\mathrm{F}} 0.44$ (40:1- 
hexane:acetone); $[\alpha]_{D}^{22}+19.0$ (c 4.52, $\mathrm{CHCl}_{3}$ ); IR $v_{\max }$ (neat) $/ \mathrm{cm}^{-1} 3076,2985,1647$, $1104 ; \delta_{\mathrm{H}}\left(400 \mathrm{MHz}, \mathrm{CDCl}_{3}\right) 4.82-4.79(1 \mathrm{H}$, brs $), 4.789-4.786(1 \mathrm{H}, \mathrm{brs}), 4.08-4.00(2 \mathrm{H}$, m), 3.90-3.87 (1H, m), 3.47-3.44 (1H, m), $3.44(3 \mathrm{H}, \mathrm{s}), 2.30-2.15(2 \mathrm{H}, \mathrm{m}), 1.79(3 \mathrm{H}, \mathrm{s})$, $1.42(3 \mathrm{H}, \mathrm{s}), 1.34(3 \mathrm{H}, \mathrm{s}) ; \delta_{\mathrm{C}}\left(100 \mathrm{MHz}, \mathrm{CDCl}_{3}\right)$ 142.2, 112.9, 108.9, 79.7, 77.4, 65.7, 58.5, 39.3, 26.3, 25.2, 22.7; m/z (ESIMS) found: $201(\mathrm{M}+1)^{+}$; calcd: 201.

Syn isomer 8; $\mathrm{R}_{\mathrm{F}} 0.27$ (40:1-hexane:acetone); $[\alpha]_{\mathrm{D}}^{22}+9.7$ (c $0.72, \mathrm{CHCl}_{3}$ ); IR $v_{\max }($ neat $) / \mathrm{cm}^{-1} 3076,2985,1647,1107 ; \delta_{\mathrm{H}}\left(400 \mathrm{MHz}, \mathrm{CDCl}_{3}\right) 4.82(1 \mathrm{H}, \mathrm{brs}), 4.78(1 \mathrm{H}$, brs), 4.19-4.14 (1H, m), $3.992(1 \mathrm{H}, \mathrm{dd}, \mathrm{J}=6.8,8.4), 3.70-3.66(1 \mathrm{H}, \mathrm{m}), 3.46(3 \mathrm{H}, \mathrm{m})$, 3.41-3.36 (1H, m), $2.73(2 \mathrm{H}, \mathrm{d}, \mathrm{J}=5.6), 1.79(3 \mathrm{H}, \mathrm{s}), 1.43(3 \mathrm{H}, \mathrm{s}), 1.36(3 \mathrm{H}, \mathrm{s}) ; \delta_{\mathrm{C}}(100$ $\left.\mathrm{MHz}, \mathrm{CDCl}_{3}\right)$ 142.1, 112.9, 109.1, 80.3, 77.6, 65.7, 58.3, 38.5, 26.4, 25.2, 22.8; $\mathrm{m} / \mathrm{z}$ (ESIMS) found: $201(\mathrm{M}+1)^{+}$; calcd: 201.

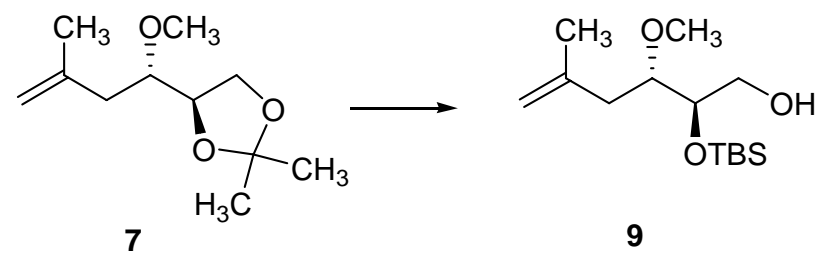

The protected diol $7(627 \mathrm{mg}, 3.1 \mathrm{mmol})$ was stirred in $6.5 \mathrm{ml}$ of $\mathrm{AcOH}: \mathrm{H}_{2} \mathrm{O}$ mixture (4:1) for $20 \mathrm{~h}$ at room temperature. The reaction mixture was concentrated and purified by FCC using with hexane:acetone (5:1) as eluent to afford $461 \mathrm{mg}(93 \%)$ diol as a colorless oil. $\mathrm{R}_{\mathrm{F}} 0.10$ (5:1-hexane:acetone); $[\alpha]^{22}{ }_{\mathrm{D}}+22.5$ (c 1.42, $\mathrm{CHCl}_{3}$ ); IR $v_{\max }($ neat $) / \mathrm{cm}^{-1} 3395,3086,2935,1649,1101 ; \delta_{\mathrm{H}}\left(400 \mathrm{MHz}, \mathrm{CDCl}_{3}\right) 4.83(1 \mathrm{H}, \mathrm{brs}), 4.79$ (1H, brs), 3.57-3.68 (3H, m), 3.52-3.48 (1H, m), $3.41(3 \mathrm{H}, \mathrm{s}), 3.00(2 \mathrm{H}, \mathrm{brs}), 2.364-2.328$ $(1 \mathrm{H}, \mathrm{m}), 2.203-2.206(1 \mathrm{H}, \mathrm{m}), 1.78(3 \mathrm{H}, \mathrm{s}) ; \delta_{\mathrm{C}}\left(100 \mathrm{MHz}, \mathrm{CDCl}_{3}\right)$ 142.2, 113.2, 81.7, 72.4, 63.1, 58.3, 38.7, 22.7; $\mathrm{m} / \mathrm{z}$ (ESIMS) found: $183(\mathrm{M}+23)^{+}$; calcd: 183.

To a solution of diol (205 mg, $1.28 \mathrm{mmol}$ ) in DMF (4 ml) was added imidazole (262 mg, $3.84 \mathrm{mmol}$ ) and $\mathrm{TBSCl}(503 \mathrm{mg}, 3.33 \mathrm{mmol}$ ). The reaction mixture was stirred overnight, and then diluted with $\mathrm{H}_{2} \mathrm{O}$. The solution was extracted with $\mathrm{Et}_{2} \mathrm{O}$, dried over $\mathrm{Na}_{2} \mathrm{SO}_{4}$. After removing the solvent in vacuo, the residue was purified by FCC using hexane:acetone (40:1) as eluent to give $437 \mathrm{mg}(88 \%)$ bis-[TBS] ether as a colorless oil. 
$\mathrm{R}_{\mathrm{F}} 0.93$ (40:1-hexane:acetone); $[\alpha]_{\mathrm{D}}^{22}-8.7$ (c 6.06, $\mathrm{CHCl}_{3}$ ); IR $v_{\max }\left(\right.$ neat) $/ \mathrm{cm}^{-1} 3076$, 2955, 1650, 1183, 1082; $\delta_{\mathrm{H}}\left(300 \mathrm{MHz}, \mathrm{CDCl}_{3}\right) 4.79$ (1H, brs), 4.80 (1H, brs), $4.77(1 \mathrm{H}$, brs), 3.82-3.77 (1H, m), $3.56(2 \mathrm{H}, \mathrm{d}, \mathrm{J}=5.7 \mathrm{~Hz}), 3.47-3.42(1 \mathrm{H}, \mathrm{m}), 3.38(3 \mathrm{H}, \mathrm{s}), 2.25$ $(2 \mathrm{H}, \mathrm{d}, \mathrm{J}=6.9 \mathrm{~Hz}), 1.77(3 \mathrm{H}, \mathrm{s}), 0.90(9 \mathrm{H}, \mathrm{s}), 0.89(9 \mathrm{H}, \mathrm{s}), 0.06(6 \mathrm{H}, \mathrm{s}), 0.07(6 \mathrm{H}, \mathrm{s}) ; \delta_{\mathrm{C}}$ (75 MHz, $\left.\mathrm{CDCl}_{3}\right)$ 143.6, 112.1, 81.3, 74.5, 64.6, 58.3, 38.7, 26.3, 26.2, 23.1, 18.6, 18.5, $-4.1,-4.3,-4.9,-5.0 ; \mathrm{m} / z$ (ESIMS) found: $411(\mathrm{M}+23)^{+} ;$calcd: 411.

To a solution of bis-[TBS] ether $(440 \mathrm{mg}, 1.13 \mathrm{mmol})$ in THF $(3.6 \mathrm{ml})$ in a plastic vial was added pyridine $(0.60 \mathrm{ml})$ and $\mathrm{HF}$-pyridine $(0.1 \mathrm{ml}$ of a $65-70 \%$ solution of $\mathrm{HF}$ in pyridine). The mixture was stirred $22 \mathrm{~h}$, then diluted with $\mathrm{Et}_{2} \mathrm{O}$ and washed with $0.5 \mathrm{M}$ $\mathrm{HCl}$ solution. The aqueous layer was re-extracted with $\mathrm{Et}_{2} \mathrm{O}$. The combined organic layers were washed with saturated $\mathrm{CuSO}_{4} \cdot \mathrm{H}_{2} \mathrm{O}$ and dried over $\mathrm{NaSO}_{4}$. After removing the solvent, the residue was purified by FCC using hexane:acetone (20:1) as eluent to give $226 \mathrm{mg}(73 \%)$ mono-alcohol 9 as a colorless oil. $\mathrm{R}_{\mathrm{F}} 0.24\left(20: 1\right.$-hexane:acetone); $[\alpha]^{22}{ }_{\mathrm{D}}$ +5.4 (c 2.98, $\left.\mathrm{CHCl}_{3}\right)$; IR $v_{\max }\left(\right.$ neat) $/ \mathrm{cm}^{-1} 3456,3076,2930,1649,1112 ; \delta_{\mathrm{H}}(400 \mathrm{MHz}$, $\left.\mathrm{CDCl}_{3}\right) 4.81$ (1H, brs), 4.79 (1H, brs) 3.73-3.60 (3H, m), $3.43(3 \mathrm{H}, \mathrm{s}), 3.41-3.39(1 \mathrm{H}, \mathrm{m})$, 2.29-2.15 (3H, m), $0.9(9 \mathrm{H}, \mathrm{s}), 0.09(6 \mathrm{H}, \mathrm{s}) ; \delta_{\mathrm{C}}\left(100 \mathrm{MHz}, \mathrm{CDCl}_{3}\right) 142.9,112.9,82.1$, 74.5, 64.1, 59.3, 40.4, 26.1, 23.1, 18.4, -4.0, -4.1; $\mathrm{m} / \mathrm{z}$ (ESIMS) found: $275(\mathrm{M}+1)^{+}$; calcd: 275.

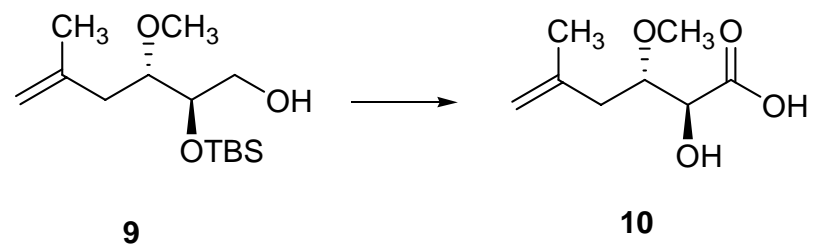

A solution of oxalyl chloride $(0.19 \mathrm{ml}, 2.18 \mathrm{mmol})$ in $\mathrm{CH}_{2} \mathrm{Cl}_{2}(7 \mathrm{ml})$ was cooled down to $-78^{\circ} \mathrm{C}$. DMSO $(0.340 \mathrm{ml}, 4.79 \mathrm{mmol})$ was syringed in one portion and stirred for $15 \mathrm{~min}$. Then the alcohol 9 (396 mg, $1.45 \mathrm{mmol})$ dissolved in $\mathrm{CH}_{2} \mathrm{Cl}_{2}(7 \mathrm{ml})$ was added slowly.

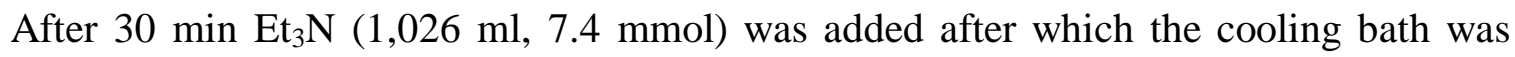
replaced by an ice bath. Stirring was continued for $20 \mathrm{~min}$, and then diluted with $\mathrm{CH}_{2} \mathrm{Cl}_{2}$ and $\mathrm{H}_{2} \mathrm{O}$. Extraction with $\mathrm{CH}_{2} \mathrm{Cl}_{2}$ and drying over $\mathrm{Na}_{2} \mathrm{SO}_{4}$ furnished $386 \mathrm{mg}(98 \%)$ aldehyde. $[\alpha]_{\mathrm{D}}^{22}-27.6$ (c 0.98, $\left.\mathrm{CHCl}_{3}\right)$; IR $v_{\max }($ neat $) / \mathrm{cm}^{-1} 3069,2955,2858,1733,1647$, 
$1109 ; \delta_{\mathrm{H}}\left(400 \mathrm{MHz}, \mathrm{CDCl}_{3}\right) 9.59(1 \mathrm{H}, \mathrm{d}, \mathrm{J}=1.1 \mathrm{~Hz}) 4.82(2 \mathrm{H}, \mathrm{brs}), 4.13(1 \mathrm{H}, \mathrm{dd}, \mathrm{J}=2.4$, $1.1 \mathrm{~Hz}), 3.60(1 \mathrm{H}, \mathrm{dt}, \mathrm{J}=7.0,2.4 \mathrm{~Hz}), 3.61(3 \mathrm{H}, \mathrm{s}), 2.33-2.21(2 \mathrm{H}, \mathrm{m}), 0.93(9 \mathrm{H}, \mathrm{s}), 0.08$ $(6 \mathrm{H}, \mathrm{d}, \mathrm{J}=8.2 \mathrm{~Hz}) ; \delta_{\mathrm{C}}\left(75 \mathrm{MHz}, \mathrm{CDCl}_{3}\right) 203.4,141.4,114.8,83.0,78.7,58.1,38.8,26.0$, 22.9, 18.5, -4.4, -4.5; m/z (ESIMS) found: $273(\mathrm{M}+1)^{+}$; calcd: 273.

A solution of aldehyde (150 mg, $0.55 \mathrm{mmol})$ in $12.5 \mathrm{ml} \mathrm{tBuOH}-\mathrm{H}_{2} \mathrm{O}$ (3.5:1) was cooled to $0{ }^{\circ} \mathrm{C}$, to which was added $\mathrm{NaH}_{2} \mathrm{PO}_{4} \mathrm{H}_{2} \mathrm{O}(137 \mathrm{mg}, 0.99 \mathrm{mmol})$, 2-methyl-2-butene (10 mmol, $5.2 \mathrm{ml}$ from $2 \mathrm{M}$ solution in THF) and $\mathrm{NaClO}_{2}(122 \mathrm{mg}, 1.35 \mathrm{mmol})$. The cooling bath was removed after $5 \mathrm{~min}$ and stirring was continued for $2 \mathrm{~h}$. The mixture was concentrated, diluted with $\mathrm{H}_{2} \mathrm{O}$, acidified with $1 \mathrm{~N} \mathrm{HCl}$ until $\mathrm{pH}$ 2-3 was reached, and then extracted with $\mathrm{Et}_{2} \mathrm{O}(5 \times)$. The organic extract was washed with brine and dried over $\mathrm{Na}_{2} \mathrm{SO}_{4}$. After removing the solvent in vacuo, the residue was purified by FCC $(50 \%$ hexane:acetone and $1 \% \mathrm{AcOH})$ to furnish $80 \mathrm{mg}(84 \%)$ carboxylic acid $\mathbf{1 0}$ as a colorless oil. $\mathrm{R}_{\mathrm{F}} 0.34$ (1:1:0.01-hexane:acetone:acetic acid); $[\alpha]^{22}{ }_{\mathrm{D}}+18.6$ (c $\left.0.86, \mathrm{CHCl}_{3}\right)$; IR $v_{\max }($ neat $) / \mathrm{cm}^{-1} 3600-2500,3395,3077,2936,1732,1651,1105 ; \delta_{\mathrm{H}}\left(300 \mathrm{MHz}, \mathrm{CDCl}_{3}\right)$ 4.87 (1H, brs), 4.84 (1H, brs), $4.40(1 \mathrm{H}, \mathrm{d}, \mathrm{J}=3.9 \mathrm{~Hz}), 3.76-3.71(1 \mathrm{H}, \mathrm{m}), 3.48$ (3H, s), 2.46-2.29 (2H, m), $1.79(3 \mathrm{H}, \mathrm{s}) ; \delta_{\mathrm{C}}\left(75 \mathrm{MHz}, \mathrm{CDCl}_{3}\right)$ 175.1, 141.4, 114.0, 81.4, 71.3, 58.3, 37.8, 23.0; m/z (ESIMS) found: $197(\mathrm{M}+23)^{+}$; calcd: 197.

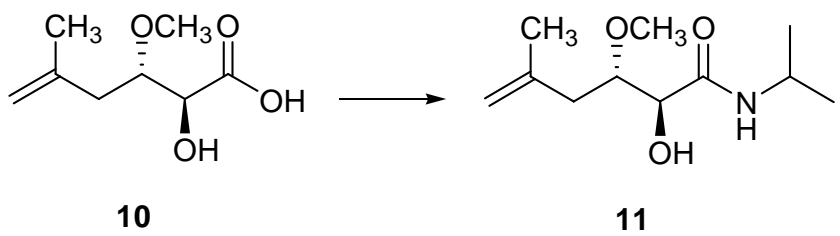

To a solution of 2-hydroxy-carboxylic acid $10(43.5 \mathrm{mg}, 0.25 \mathrm{mmol})$, catalytic amount of DMAP ( 1 mg), and pyridine (43 $\mu \mathrm{l}, 0.53 \mathrm{mmol})$ was added TMSCl (68 $\mu \mathrm{l}, 0.53 \mathrm{mmol})$ dropwise. The reaction was stirred at room temperature for $3 \mathrm{~h}$. The reaction was cooled to $0{ }^{\circ} \mathrm{C}$ and catalytic DMF ( 1 drop) was added followed by oxalyl chloride ( $25 \mu \mathrm{l}, 0.28$ mmol). The reaction mixture was stirred for $30 \mathrm{~min}$ at $0{ }^{\circ} \mathrm{C}$ and then $30 \mathrm{~min}$ at room temperature. After cooling the mixture to $0{ }^{\circ} \mathrm{C}$, a solution of isopropyl amine ( $43 \mu \mathrm{l}, 0.5$ mmol $)$ in pyridine $(121 \mu \mathrm{l}, 1.5 \mathrm{mmol})$ was added and the reaction was allowed to warm to room temperature and stir for $2 \mathrm{~h}$. Citric acid $(111.3 \mathrm{mg}, 0.53 \mathrm{mmol})$ was dissolved in methanol $(1 \mathrm{ml})$ and added to the reaction. After $45 \mathrm{~min}$, the mixture was poured into o 
separatory funnel and diluted with ethyl acetate. The organic phase was washed with $1 \mathrm{~N}$ $\mathrm{HCl}$ and the aqueous wash was back extracted with ethyl acetate. The combined organic layers were washed with a saturated bicarbonate solution followed by brine and dried over $\mathrm{Na}_{2} \mathrm{SO}_{4}$. After removing the solvent, the residue was purified by FCC using hexane:acetone (5:1) as eluent to furnish $27 \mathrm{mg}$ (50\%) amide 11 as a white solid. For crystallization, $1 \mathrm{mg}$ of purified compound $\mathbf{1 1}$ was dissolved in $1 \mathrm{ml}$ of $\mathrm{CH}_{2} \mathrm{Cl}_{2}$, and then almost $1 \mathrm{ml}$ of hexane was added until turbidity appeared. Colorless crystals were obtained in next day. $\mathrm{R}_{\mathrm{F}} 0.36$ (5:1-hexane:acetone); $[\alpha]^{22}{ }_{\mathrm{D}}-24.2$ (c 0.99, $\mathrm{CHCl}_{3}$ ); IR (KBr) 3391, 3285, 3077, 2974, 1650, 1648, 1104; $\delta_{\mathrm{H}}\left(300 \mathrm{MHz}, \mathrm{CD}_{3} \mathrm{OD}\right) 4.76(1 \mathrm{H}, \mathrm{s})$, $4.73(1 \mathrm{H}, \mathrm{s}), 4.26(1 \mathrm{H}, \mathrm{d}, \mathrm{J}=3 \mathrm{~Hz}), 4.00(1 \mathrm{H}, \mathrm{m}, \mathrm{J}=6.6 \mathrm{~Hz}), 3.66(1 \mathrm{H}, \mathrm{dt}, \mathrm{J}=9.3,3.0), 3.38$ $(3 \mathrm{H}, \mathrm{s}), 2.27(1 \mathrm{H}, \mathrm{ddd}, \mathrm{J}=14,9.3,0.6), 2.05(1 \mathrm{H}, \mathrm{dd}, \mathrm{J}=14,3.6), 1.73(3 \mathrm{H}, \mathrm{s}), 1.56(6 \mathrm{H}$, dd, J=6.6, $4.5 \mathrm{~Hz})$; (75 MHz, $\left.\mathrm{CDCl}_{3}\right)$ 172.3, 142.6, 111.7, 81.4, 71.2, 56.5, 41.1, 37.2, 21.8, 21.48, 21.43; $\mathrm{m} / \mathrm{z}$ (ESIMS) found: $216(\mathrm{M}+1)^{+}$; calcd: 216.

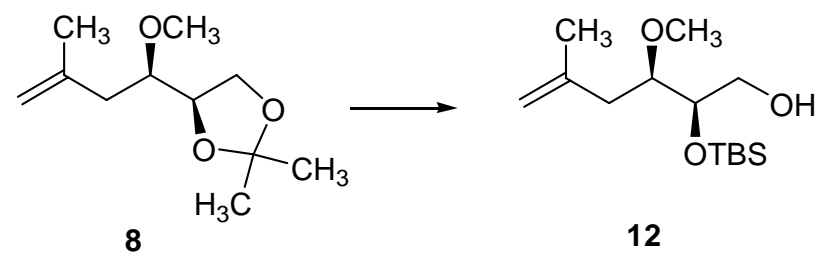

The protected diol $8(627 \mathrm{mg}, 3.1 \mathrm{mmol})$ was stirred in $6.5 \mathrm{ml}$ of $\mathrm{AcOH}: \mathrm{H}_{2} \mathrm{O}$ mixture (4:1) for $20 \mathrm{~h}$ at room temperature. The reaction mixture was concentrated and purified by FCC using hexane:acetone (5:1) as eluent to afford $436 \mathrm{mg}$ (88\%) diol as a colorless oil. $\mathrm{R}_{\mathrm{F}} 0.08$ (5:1-hexane:acetone); $[\alpha]^{22}{ }_{\mathrm{D}}-29.2$ (c $0.24, \mathrm{CHCl}_{3}$ ); IR $v_{\max }$ (neat) $/ \mathrm{cm}^{-1} 3076$, 2985, 1647, 1107; $\delta_{\mathrm{H}}\left(400 \mathrm{MHz}, \mathrm{CDCl}_{3}\right) 4.82(1 \mathrm{H}, \mathrm{brs}), 4.78(1 \mathrm{H}, \mathrm{brs}), 4.19-4.14(1 \mathrm{H}$, m), $3.992(1 \mathrm{H}, \mathrm{dd}, \mathrm{J}=6.8,8.4), 3.70-3.66(1 \mathrm{H}, \mathrm{m}), 3.46(3 \mathrm{H}, \mathrm{m}), 3.41-3.36(1 \mathrm{H}, \mathrm{m}), 2.73$ $(2 \mathrm{H}, \mathrm{d}, \mathrm{J}=5.6), 1.79(3 \mathrm{H}, \mathrm{s}), 1.43(3 \mathrm{H}, \mathrm{s}), 1.36(3 \mathrm{H}, \mathrm{s}) ; \delta_{\mathrm{C}}\left(100 \mathrm{MHz}, \mathrm{CDCl}_{3}\right)$ 142.0, 113.4, 79.9, 72.7, 64.0, 57.9, 38.1, 22.8; $\mathrm{m} / z$ (ESIMS) found: $201(\mathrm{M}+1)^{+}$; calcd: 201.

To a solution of the above diol (205 mg, $1.28 \mathrm{mmol})$ in DMF (4 ml) was added imidazole (262 mg, $3.84 \mathrm{mmol})$ and $\mathrm{TBSCl}(503 \mathrm{mg}, 3.33 \mathrm{mmol})$. The reaction mixture was stirred overnight and then diluted with $\mathrm{H}_{2} \mathrm{O}$, extracted with $\mathrm{Et}_{2} \mathrm{O}$, and dried over $\mathrm{Na}_{2} \mathrm{SO}_{4}$. After removing the solvent in vacuo, the residue was purified by FCC using hexane:acetone 
(40:1) as eluent to give $457 \mathrm{mg}$ (92\%) bis-TBS ether as a colorless oil. $\mathrm{R}_{\mathrm{F}} 0.93$ (40:1hexane:acetone); $[\alpha]^{22}{ }_{\mathrm{D}}+5.6$ (c 0.90, $\mathrm{CHCl}_{3}$ ); $\mathrm{IR} v_{\max }($ neat $) / \mathrm{cm}^{-1}$ 3076, 2955, 1648, 1111; $\delta_{\mathrm{H}}\left(400 \mathrm{MHz}, \mathrm{CDCl}_{3}\right) 4.79(1 \mathrm{H}, \mathrm{brs}), 4.76(1 \mathrm{H}, \mathrm{brs}), 3.80-3.72(2 \mathrm{H}, \mathrm{m}), 3.53-3.49(1 \mathrm{H}$, m), 3.43-3.40 (1H, m), $3.40(3 \mathrm{H}, \mathrm{s}), 2.330(1 \mathrm{H}, \mathrm{dd}, \mathrm{J}=14.4,2.8), 2.10(1 \mathrm{H}, \mathrm{dd}, \mathrm{J}=14.4$, 9.2), $0.90(18 \mathrm{H}, \mathrm{s}), 0.09(6 \mathrm{H}, \mathrm{s}), 0.06(6 \mathrm{H}, \mathrm{brs}) ; \delta_{\mathrm{C}}\left(400 \mathrm{MHz}, \mathrm{CDCl}_{3}\right) 143.8,112.2,80.8$, 74.1, 64.2, 58.6, 38.0, 26.2, 26.1, 22.9, 18.5, 18.3, -3.9, -4.5, -5.0, -5.1; m/z (ESIMS) found: $411(\mathrm{M}+23)^{+}$; calcd: 411 .

To a solution of bis-TBS ether $(440 \mathrm{mg}, 1.13 \mathrm{mmol})$ in THF $(3.6 \mathrm{ml})$ in a plastic vial was added pyridine $(0.60 \mathrm{ml})$ and $\mathrm{HF}-$ pyridine $(0.1 \mathrm{ml}$ of a $65-70 \%$ solution of $\mathrm{HF}$ in pyridine). The mixture was stirred $22 \mathrm{~h}$, then diluted with $\mathrm{Et}_{2} \mathrm{O}$ and washed with $0.5 \mathrm{M}$ $\mathrm{HCl}$ solution. The aqueous layer was re-extracted with $\mathrm{Et}_{2} \mathrm{O}$. The combined organic layers were washed with saturated $\mathrm{CuSO}_{4} \mathrm{H}_{2} \mathrm{O}$ and dried over $\mathrm{NaSO}_{4}$. After removing the solvent, the residue was purified by FCC using hexane:acetone (20:1) as eluent to give $229 \mathrm{mg}(74 \%)$ alcohol 12 as a colorless oil. $\mathrm{R}_{\mathrm{F}} 0.24$ (20:1-hexane:acetone); $[\alpha]^{22}+3.3$ (c 1.80, $\mathrm{CHCl}_{3}$ ); IR $v_{\max }\left(\right.$ neat) $/ \mathrm{cm}^{-1} 3461,3076,2930,1647,1107 ;\left(400 \mathrm{MHz}, \mathrm{CDCl}_{3}\right) 4.80$ $(1 \mathrm{H}, \mathrm{brs}), 4.77(1 \mathrm{H}, \mathrm{brs}), 3.93-3.89(1 \mathrm{H}, \mathrm{m}), 3.72-3.68(1 \mathrm{H}, \mathrm{m}), 3.58-3.54(1 \mathrm{H}, \mathrm{m}), 3.43-$ $3.418(1 \mathrm{H}, \mathrm{m}), 3.410(3 \mathrm{H}, \mathrm{s}), 2.36(1 \mathrm{H}, \mathrm{d}, \mathrm{J}=14.4 \mathrm{~Hz}), 2.24(1 \mathrm{H}, \mathrm{brs}), 2.12(1 \mathrm{H}, \mathrm{dd}$, $\mathrm{J}=14.4,9.6 \mathrm{~Hz}), 1.77(3 \mathrm{H}, \mathrm{s}), 0.90(9 \mathrm{H}, \mathrm{s}), 0.11(6 \mathrm{H}, \mathrm{s}) ; \delta_{\mathrm{C}}\left(100 \mathrm{MHz}, \mathrm{CDCl}_{3}\right) 143.3$, $112.5,82.3,71.9,63.8,58.7,37.8,26.1,23.1,18.4,-4.2 ; \mathrm{m} / z$ (ESIMS) found: 275 $(\mathrm{M}+1)^{+}$; calcd: 275 .

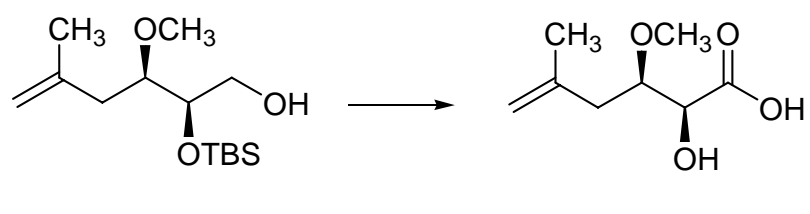

12

13

A solution of oxalyl chloride $(0.19 \mathrm{ml}, 2.18 \mathrm{mmol})$ in $\mathrm{CH}_{2} \mathrm{Cl}_{2}(7 \mathrm{ml})$ was cooled down to $-78^{\circ} \mathrm{C}$. DMSO $(0.340 \mathrm{ml}, 4.79 \mathrm{mmol})$ was syringed in one portion and stirred for $15 \mathrm{~min}$. Then the alcohol 12 (396 mg, $1.45 \mathrm{mmol})$ dissolved in $\mathrm{CH}_{2} \mathrm{Cl}_{2}$ (7 ml) was added slowly. After 30 min $\mathrm{Et}_{3} \mathrm{~N}(1,026 \mathrm{ml}, 7.4 \mathrm{mmol})$ was added after which the cooling bath was replaced by an ice bath. Stirring was continued for $20 \mathrm{~min}$, and then diluted with $\mathrm{CH}_{2} \mathrm{Cl}_{2}$ 
and $\mathrm{H}_{2} \mathrm{O}$. Extraction with $\mathrm{CH}_{2} \mathrm{Cl}_{2}$ and drying over $\mathrm{Na}_{2} \mathrm{SO}_{4}$ furnished $386 \mathrm{mg}(98 \%)$ aldehyde. $[\alpha]_{D}^{22}-5.9$ (c 1.18, $\mathrm{CHCl}_{3}$ ); IR $v_{\max }$ (neat) $/ \mathrm{cm}^{-1} 3078,2932,2858,1736,1648$, 1099; $\delta_{\mathrm{H}}\left(400 \mathrm{MHz}, \mathrm{CDCl}_{3}\right) 9.69(1 \mathrm{H}, \mathrm{d}, \mathrm{J}=1.2 \mathrm{~Hz}), 4.79$ (1H, brs), 4.75 (1H, brs), 4.07 $(1 \mathrm{H}, \mathrm{dd}, \mathrm{J}=3.9,1.2 \mathrm{~Hz}), 3.66-3.61(1 \mathrm{H}, \mathrm{m}), 3.35$ (3H, s), 2.34-2.29 (1H, m), 2,24-2.17 $(1 \mathrm{H}, \mathrm{m}), 0.91(9 \mathrm{H}, \mathrm{s}), 0.05(6 \mathrm{H}, \mathrm{d}, \mathrm{J}=7.6 \mathrm{~Hz}) ; \delta_{\mathrm{C}}\left(75 \mathrm{MHz}, \mathrm{CDCl}_{3}\right)$ 203.7, 142.2, 113.1, 81.5, 78.7, 58.7, 38.4, 26.1, 23.1, 18.6, -4.1, -4.6; $\mathrm{m} / \mathrm{z}$ (ESIMS) found: $273(\mathrm{M}+1)^{+}$; calcd: 273.

A solution of aldehyde $(150 \mathrm{mg}, 0.55 \mathrm{mmol})$ in $12.5 \mathrm{ml}$ of $\mathrm{tBuOH}-\mathrm{H}_{2} \mathrm{O}$ (3.5:1) was cooled to $0{ }^{\circ} \mathrm{C}$ and added $\mathrm{NaH}_{2} \mathrm{PO}_{4} \mathrm{H}_{2} \mathrm{O}$ (137 mg, $\left.0.99 \mathrm{mmol}\right)$, 2-methyl-2-butene (10 mmol, $5.2 \mathrm{ml}$ from $2 \mathrm{M}$ solution in THF) and $\mathrm{NaClO}_{2}(122 \mathrm{mg}, 1.35 \mathrm{mmol})$. The cooling bath was removed after $5 \mathrm{~min}$ and stirring was continued for $2 \mathrm{~h}$. The mixture was concentrated, diluted with $\mathrm{H}_{2} \mathrm{O}$, and then $1 \mathrm{~N} \mathrm{HCl}$ was added until $\mathrm{pH}$ 2-3 was reached. The mixture was extracted with $\mathrm{Et}_{2} \mathrm{O}(5 \times)$, and the combined organic extract was washed with brine and dried over $\mathrm{Na}_{2} \mathrm{SO}_{4}$. After removing the solvent in vacuo, the residue was purified by FCC (50\% hexane:acetone and 1\% AcOH) to furnish $77 \mathrm{mg}(80 \%)$ carboxylic acid 13 as a colorless oil. $R_{F} 0.34$ (1:1:0.01-hexane:acetone:acetic acid); $[\alpha]^{22}{ }_{D}+6.0$ (c $\left.1.16, \mathrm{CHCl}_{3}\right)$; IR $v_{\max }\left(\right.$ neat) $/ \mathrm{cm}^{-1} 3600-2600,3346,3076,2936,1732,1650,1089 ; \delta_{\mathrm{H}}$ (300 MHz, CDCl $\left.{ }_{3}\right) 4.87$ (1H, brs), $4.84(1 \mathrm{H}$, brs), $4.21(1 \mathrm{H}, \mathrm{s}), 3.83(1 \mathrm{H}, \mathrm{t}, \mathrm{J}=7.2 \mathrm{~Hz})$, $3.40(3 \mathrm{H}, \mathrm{s}), 2.38(2 \mathrm{H}, \mathrm{d}, \mathrm{J}=7.2 \mathrm{~Hz})$; $\left(75 \mathrm{MHz}, \mathrm{CDCl}_{3}\right)$ 177.3 (s), 141.3, 114.3, 80.2, 71.3, 58.5, 38.2, 23.1; $\mathrm{m} / \mathrm{z}$ (ESIMS) found: $197(\mathrm{M}+23)^{+}$; calcd: 197.

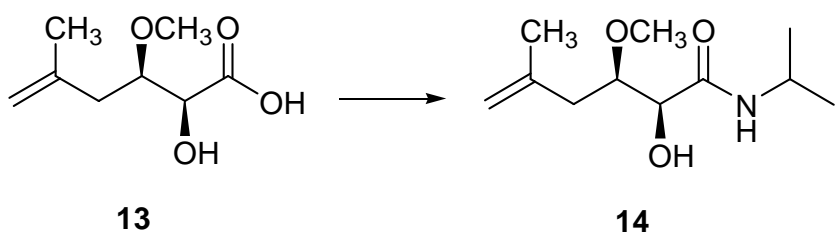

To a solution of 2-hydroxy-carboxylic acid $13(43.5 \mathrm{mg}, 0.25 \mathrm{mmol})$, catalytic amount of DMAP, and pyridine (43 $\mu \mathrm{l}, 0.53 \mathrm{mmol})$ was added TMSCl $(68 \mu \mathrm{l}, 0.53 \mathrm{mmol})$ dropwise. The reaction was stirred at room temperature for $3 \mathrm{~h}$. The reaction was cooled to $0{ }^{\circ} \mathrm{C}$ and catalytic amount of DMF (1 drop) was added followed by oxalyl chloride ( $25 \mu 1,0.28$ mmol). The reaction mixture was stirred for $30 \mathrm{~min}$ at $0{ }^{\circ} \mathrm{C}$ and then $30 \mathrm{~min}$ at room temperature. After cooling the mixture to $0{ }^{\circ} \mathrm{C}$, a solution of isopropyl amine ( $43 \mu 1,0.5$ 
mmol) in pyridine ( $121 \mu \mathrm{l}, 1.5 \mathrm{mmol}$ ) was added and the reaction was allowed to warm to room temperature and stir for $2 \mathrm{~h}$. Citric acid $(111.3 \mathrm{mg}, 0.53 \mathrm{mmol})$ was dissolved in methanol (1 ml) and added to the reaction. After $45 \mathrm{~min}$, the mixture was poured into a separatory funnel and diluted with ethyl acetate. The organic phase was washed with $1 \mathrm{~N}$ $\mathrm{HCl}$ and the aqueous wash was back extracted with ethyl acetate. The combined organic layers were washed with a saturated bicarbonate solution followed by brine and dried over $\mathrm{Na}_{2} \mathrm{SO}_{4}$. After removing the solvent, the residue was purified by FCC using hexane:acetone (5:1) as eluent to furnish $29 \mathrm{mg}$ (54\%) amide $\mathbf{1 4}$ as a colorless oil. M.p. 62-63 ${ }^{\circ} \mathrm{C} ; \mathrm{R}_{\mathrm{F}} 0.36$ (5:1-hexane:acetone); $[\alpha]^{22}{ }_{\mathrm{D}}-26.7$ (c 2.32, $\mathrm{CHCl}_{3}$ ); IR $v_{\max }$ (neat) $/ \mathrm{cm}^{-1}$ $3390,3340,3076,2971,1650,1090 ; \delta_{\mathrm{H}}\left(300 \mathrm{MHz}, \mathrm{CD}_{3} \mathrm{OD}\right) 4.84-4.83$ (1H, brs), 4.81$4.80(1 \mathrm{H}, \mathrm{brs}), 4.02(1 \mathrm{H}, \mathrm{m}, \mathrm{J}=6.6 \mathrm{~Hz}), 3.90(1 \mathrm{H}, \mathrm{d}, \mathrm{J}=1.8 \mathrm{~Hz}), 3.83-3.77(1 \mathrm{H}, \mathrm{m}), 3.33$ $(3 \mathrm{H}, \mathrm{s}), 2.40-2.26(2 \mathrm{H}, \mathrm{m}), 1.80(3 \mathrm{H}, \mathrm{s}), 1.17(6 \mathrm{H}, \mathrm{dd}, \mathrm{J}=6.6,2.4 \mathrm{~Hz}) ;\left(75 \mathrm{MHz}, \mathrm{CDCl}_{3}\right)$ 173.4, 142.2, 112.6, 80.2, 72.2, 57.8, 41.2, 38.6, 21.8, 21.5, 21.4; $\mathrm{m} / z$ (ESIMS) found: $216(\mathrm{M}+1)^{+}$; calcd: 216. 